\title{
COXEN Score 10
}

National Cancer Institute

\section{Source}

National Cancer Institute. COXEN Score 10. NCI Thesaurus. Code C128207.

A score of 10 on the COXEN Sensitivity Scale. 